\title{
Prevalence, phenotypic and genotypic characterization, virulence potential and antimicrobial resistance of Cronobacter species from ready-to-eat foods
}

Seza Arslan ( $\square$ arslan_s3@ibu.edu.tr)

https://orcid.org/0000-0002-2478-6875

Hafize Gizem Ertürk

Abant Izzet Baysal Universitesi Fen Edebiyat Fakultesi

Research article

Keywords: Cronobacter species, Ready-to-eat food, Isolation, Identification, ERIC-PCR, Virulence characteristics, Antimicrobial resistance

Posted Date: August 28th, 2019

DOI: https://doi.org/10.21203/rs.2.13644/v1

License: (c) (1) This work is licensed under a Creative Commons Attribution 4.0 International License. Read Full License 


\section{Abstract}

Background Cronobacter, an emerging foodborne pathogen, contaminates various foods such as ready-to-eat (RTE) food due to its ubiquitous nature. Consumption of food contaminated with Cronobacter can cause severe infections in children, elderly or immunocompromised people. Therefore, we aimed to assess the presence of Cronobacter spp. in RTE foods, popularly consumed products, and pose potential health threat for consumers, especially for risk groups. Results Out of 340 RTE food samples, 59 (17.4\%) were contaminated with Cronobacter spp. in this study. The highest contamination rate was found in meat free cig koftes (51.9\%, 14/27), followed by spices (46.7\%, 7/15), cereals (30.8\%, 4/13), and desserts $(30.2 \%, 13 / 43)$. A total of 64 Cronobacter isolates were identified phenotypically and genotypically from the 59 ready-to-eat foods samples. Molecular characterization was accomplished by PCR targeting $16 \mathrm{~S}$ rRNA, gluA, rpoB and cgcA genes. The 64 Cronobacter isolates were completely identified by the biochemical and $r p o B$, while the PCR targeting the cgcA gene failed to identify to eight isolates. In this study, we investigated major virulence characteristics contributing to the pathogenicity of Cronobacter spp. including the outer membrane protein A, zincmetalloprotease, siderophore production and biofilm formation. Many Cronobacter isolates (>87\%) had these virulence characteristics. All isolates and a type strain were characterized using ERIC-PCR and genetic profiles of cluster analysis showed that the isolates were highly heterogeneous and genetically diverse. Antimicrobial susceptibility of RTE isolates to 18 different antimicrobial agents was determined by the disc diffusion method. Most Cronobacter isolates with a rate of $81.3 \%$ were resistant to cephalothin, $32.8 \%$ to cefoxitin and $20.3 \%$ to ampicillin All Cronobacter isolates were susceptible to gentamicin and trimethoprim/sulfamethoxazole. The multidrug resistance to at least three or more antimicrobial agents was detected in $18.8 \%$ of Cronobacter isolates.Conclusions Results indicate that RTE food harbors potential pathogenic Cronobacter species and is a possible transmission vehicle for Cronobacter infection in vulnerable person. So, there is a need to adopt hygienic practices and rigorous sanitization treatments to ensure microbiological safety of RTE food.

\section{Background}

Cronobacter spp. are recognized as Gram-negative rod, non-spore forming within the Enterobacteriaceae family [1]. The genus Cronobacter contains seven species: Cronobacter sakazakii, Cronobacter malonaticus, Cronobacter turicensis, Cronobacter muytjensii, Cronobacter dublinensis, Cronobacter universalis and Cronobacter condimenti [2, 3]. These organisms are extensively found in the environment and food products including powdered milk, powdered infant formula, vegetables, salads, herbs, cereal, chocolate, milk, meat, potato flour, pasta and spices $[4,5]$.

Cronobacter is considered to be an opportunistic pathogen implicated in several diseases including necrotizing enterocolitis, bacteremia, and meningitis [1, 6]. In 2002, the International Commission for Microbiological Specifications for Foods (ICMSF) classified Cronobacter as a serious threat for restricted populations, causing life-threatening or considerable illness of extended period, with the high-risk populations being newborns and immunocompromised infants [7]. The symptoms of Cronobacter infections are high fever, headache with nausea, a swelling on the head, body and neck stiffness, skin rash, seizures, urosepsis, pneumonia [8]. All Cronobacter species have been associated with human infections except for $C$. condimenti. Cronobacter infections in neonates and infant seem to be particularly concerned with species of $C$. sakazakii $[8,9,10]$. In addition, $C$. malonaticus has been commonly linked to adult infections. Moreover, a single case of neonatal meningitis has been relevant with $C$. turicensis infection [1]. Whereas Cronobacter spp. based human infections are not common, the mortality rate of these pathogens are considerable (40-80\%) in infected human, especially in neonates. Even if these people survive, they often suffer from severe neurological complications $[8,11]$.

Cronobacter species have various virulence traits which are responsible for their pathogenicity [12]. The virulence factors are adhesion proteins, cell-surface proteins, toxins, proteolytic enzymes, biofilm formation and siderophore production. The adhesion and tissue invasion in the host and cell injury are considered as the main pathogenic route for Cronobacter infection [12, 13]. The outer membrane protein A (OmpA) encoded by the ompA gene is the best described virulence marker and has a significant role in Cronobacterinvasion [14]. The OmpA of Cronobacter plays a role in the colonization of the gastrointestinal tract [15] and the ompA-positive isolates break blood-brain barrier and invade central nervous system causing clinical symptoms [16]. Furthermore, it was reported that the zinc-containing metalloprotease encoded the $z p x$ gene caused rounding of Chinese Hamster Ovary cells in tissue culture in the clinical and environmental Cronobacter strains [13]. This gene may help as an indicator of pathogenicity $[16,17]$. Biofilm formation, caused by some pathogens, has a role as physical protective barrier and is described as unity of bacterial cells [18]. The biofilms are surrounded by a self-producing matrix and adherent to an inert or living surface. Cronobacter has been reported to form biofilms on latex, stainless steel, glass, silicon, polyvinyl chloride and polycarbonate [18]. Moreover, siderophores, low molecular weight compounds having a high affinity for iron ions, play a role in the virulence of Cronobacterspp. [19].

A great many methods for identification and description of Cronobacterspp. have been suggested since it was defined by Farmer et al. [6]. Muytjens et al. [20] described the initial detection and isolation method developed for Cronobacter species. The Food and Drug Administration (FDA) and the International Organization for Standardization (ISO) improved protocols for the isolation and detection of Cronobacter spp. [21, 22]. Cronobacter species have been identified and classified genotypically using amplification of 16S rRNA gene, the gluA gene, the enterobacterial repetitive intergenic consensus (ERIC) sequences, pulsed-field gel electrophoresis (PFGE), multilocus sequence typing (MLST), ribotyping and plasmid typing [5, 23-25]. Moreover, the rpoB gene-based PCR method was improved to differentiate between the seven

Page 2/18 
Cronobacter species. It has been known that the bacterial RNA polymerase $\beta$-subunit is encoded by this universal gene and its suitability in species definition has been evaluated $[26,27]$. Furthermore, gene $c g c A$ encoding a diguanylate cyclase which is involved in virulence, biofilm production and survival of the organism has also been used as the genetic marker to distinguish Cronobacter species [28].

Cronobacter may express $\beta$-lactamases, thus conferring resistance against a range of cephalosporins and penicillins [29]. The treatment of Cronobacter meningitis has shifted to extended-spectrum cephalosporins, sometimes in combination with a second agent, e.g., trimethoprim [11]. Cronobacter spp. are susceptible to commonly used antimicrobials such as aminogylcosides, ureidopenicillins, ampicillin, and carboxypenicillins $[9,29,30]$. However, antimicrobial resistant strains of Cronobacter spp., some of which have multiple drug resistance, were reported in various studies [31, 32]. The emergence of resistant Cronobacterspp. and transmission of these resistant species from food to human may be a significant problem for treatment of Cronobacter infections $[5,11]$

Today, a growing number of people are buying ready-to-eat foods since they are easy and practical to prepare, and delicious foods to consume [33]. Ready-to-eat foods that are usually high in protein and ready to eat without further heating or cooking are known as high-risk foods and provide excellent conditions for bacterial growth [34]. Cronobacter, a ubiquitous foodborne pathogen, can cause severe infections in immunocompromised people over the world. In Turkey, several studies focused on isolation and identification of Cronobacter spp. from samples of milk powder, powdered infant formula and cereal-based products [35,36], but there is little data on the prevalence of Cronobacter spp. in readyto-eat foods. Therefore, this study aims to determine the prevalence of Cronobacter species in ready-to-eat foods, to identify the Cronobacter species by phenotypic and genotypic methods, and to evaluate virulence factors, antimicrobial susceptibility and genetic relatedness of Cronobacterisolates.

\section{Methods}

\section{Sample collection}

A total of 340 ready-to-eat food samples were purchased from markets, local bazaar, patisserie and herbalist from January 2016 to December 2016 in Bolu (Western Turkey). The samples included 49 doners (thinly sliced doner kebab from chicken and beef), 43 desserts, 41 pastrami (seasoned, air-dried, cured, smoked, and non-fermented beef cut), 40 cheeses, 38 salads, 35 kavurma (sliced and fried meat from beef or mutton), 27 cigkoftes (meatless and uncooked bulgur product), 27 ice cream, 15 spices, 13 cereals, 7 herbs, and 5 vegetables. These samples were transported to the laboratory in a cold box (below $4^{\circ} \mathrm{C}$ ) and immediately analyzed.

\section{Isolation and phenotypically identification of Cronobacterspp.}

Cronobacter spp. were isolated according to the methods of the Food and Drug Administration [21] and the International Standard Organization [22] with some modification. According to FDA [21], for each sample, $225 \mathrm{~mL}$ of buffered peptone water (BPW; Merck, Darmstadt, Germany) were added to $25 \mathrm{~g}$ of sample. After homogenizing in a stomacher (Interscience, Saint-Nom-la-Breteche, France) for $60 \mathrm{~s}$, samples were incubated at $37^{\circ} \mathrm{C}$ for $24 \mathrm{~h}$. Then, $10 \mathrm{~mL}$ of pre-enrichment broth was added to $90 \mathrm{~mL}$ of Enterobacteriaceae Enrichment Broth (Merck). Following an overnight incubation at $37^{\circ} \mathrm{C}$, these cultures were streaked onto Violet Red Bile Glucose agar (VRBG; Merck, Germany), Violet Red Bile Lactose agar (VRBL; Merck, Germany), and Tryptic Soy Agar (TSA; Merck, Germany) and incubated for $24 \mathrm{~h}$ at $37^{\circ} \mathrm{C}$. The ISO/ TS 22964 [22] method with some modification; a $25 \mathrm{~g}$ of each sample was homogenizated with $225 \mathrm{~mL}$ BPW and incubated for $24 \mathrm{~h}$ at $37^{\circ} \mathrm{C} .1 \mathrm{~mL}$ of BPW pre-enrichment was added to $10 \mathrm{~mL}$ modified Lauryl Sulfate Tryptose (Merck) broth supplemented with $0.5 \mathrm{M} \mathrm{NaCl}$ and 0.1 mg/L vancomycin and incubated for $24 \mathrm{~h}$ at $44^{\circ} \mathrm{C}$. After incubation, a loopful of $\mathrm{mLST}$ broth was streaked onto VRBG agar and VRBL agar at $44^{\circ} \mathrm{C} / 24 \mathrm{~h}$, while TSA incubated at $25^{\circ} \mathrm{C} / 48$ h. Then, all colonies counted as Cronobacter spp. were subcultured on TSA medium. Five suspect yellow pigment colonies of Cronobacter spp. were subjected to the following biochemical tests for identification: Gram staining; oxidase and catalase test; motility assessment; indole production; utilization of citrate and malonate; Voges-Proskauer (acetoin production) reaction; lysine decarboxylase; utilization of carbohydrates such as dulcitol, sucrose, trans-aconitate, cis-aconitate, myo-inositol, lactulose, maltitol, melezitose, 4-aminobutyrate, and 10-methyl a-Dglucopyranoside [2, 3, 6]. Cronobacter sakazakii ATCC 29544 was used as a reference strain in all biochemical and molecular experiments.

\section{Genus-specific identification of Cronobacterspp. using PCR}

The genomic DNA extraction to use in all PCR experiments was performed using a previously described method [59]. All Cronobacterisolates were grown on TSA for $24 \mathrm{~h}$ at $37^{\circ} \mathrm{C}$. One colony of each culture was added into $5 \mathrm{~mL}$ Brain Heart Infusion (Merck) broth and was incubated at $37^{\circ} \mathrm{C}$ for $18 \mathrm{~h}$. The extracted DNA was kept at $-20^{\circ} \mathrm{C}$ for further use.

For the genus-specific identification, the 16S rRNA gene [25] and the gluA gene [24] were used in all isolates. The primer sequences, expected size of amplification products and references are presented in Table 3. PCR amplification of 16S rRNA was performed in a total volume of $30 \mu \mathrm{L}$, with the following reagent concentration: $3 \mu \mathrm{L}$ of $10 \times \mathrm{PCR}$ buffer $\left(500 \mathrm{mM} \mathrm{KCl}, 100 \mathrm{mM}\right.$ Tris- $\mathrm{HCl}, \mathrm{pH} 9.1,0.1 \%$ Triton ${ }^{\mathrm{TM}} \mathrm{X}-100$, Vivantis Techologies Sdn. Bhn., Kuala Lumpur, Malaysia), $1.8 \mu \mathrm{L}$ of $50 \mathrm{mM} \mathrm{MgCl}$ (Vivantis), $0.6 \mu \mathrm{L}$ of $10 \mathrm{mM}$ dNTP mix (Vivantis), $1 \mu \mathrm{L}$ of $10 \mu \mathrm{M}$ each of the primers (Biomers, Ulm, Germany), $2.5 \mu \mathrm{L}$ of template DNA (50 ng/ $\mu \mathrm{L}$ ), $1.25 \mathrm{U}$ Taq DNA polymerase (Vivantis) and $19.85 \mu \mathrm{L}$ molecular grade water 
(AppliChem, Darmstadt, Germany). The thermal cycling conditions were as follows: initial denaturation at $94^{\circ} \mathrm{C}$ for 4 min, followed by 30 cycles of denaturation at $95^{\circ} \mathrm{C}$ for $1 \mathrm{~min}$; annealing at $57^{\circ} \mathrm{C}$ for $1 \mathrm{~min}$, and elongation at $72^{\circ} \mathrm{C}$ for $1 \mathrm{~min} 30 \mathrm{~s}$, and a final extension at $72^{\circ} \mathrm{C}$ for 4 min.

For the gluA gene amplification, cycling conditions for amplification of DNA fragments was performed as described by Lehner et al. [24]. All PCR mixtures contained $5 \mu \mathrm{L} 10 \times$ PCR buffer (Vivantis), $4 \mu \mathrm{L}$ of $50 \mathrm{mM} \mathrm{MgCl}_{2}$ (Vivantis), $1 \mu \mathrm{L}$ of $10 \mathrm{mM}$ dNTP mix (Vivantis), $2 \mu \mathrm{L}$ of $10 \mu \mathrm{M}$ each primers (Biomers), $3 \mu \mathrm{L}$ of target DNA (50 ng/ $\mu \mathrm{L}), 3 \cup$ Taq DNA polymerase (Vivantis) and $32.4 \mu \mathrm{L}$ molecular grade water (AppliChem).

\section{Species-specific identification of Cronobacter spp. using PCR}

Two PCR assays targeting the $r p o B$ gene and the $c g c A$ gene were used to identify Cronobacter species. Identification of the seven species of Cronobacter including $C$. condimenti, $C$. dublinensis, $C$. malonaticus, $C$. muytjensii, $C$. sakazakii, $C$. turicensis and $C$. universalis was carried out with the appropriate primer sets for the $r p o B$ gene $[26,27]$. The PCR reaction mixture included $5 \mu \mathrm{L}$ of $10 \times \mathrm{PCR}_{\text {buffer }}(\mathrm{Vivantis}), 4 \mathrm{mM} \mathrm{MgCl}_{2}$ (Vivantis), $0.2 \mathrm{mM}$ dNTP mix (Vivantis), $0.4 \mu \mathrm{M}$ of each primer (Biomers), $3 \mu \mathrm{L}$ of template DNA (50 ng/ $\mu \mathrm{L}$ ) and $2 \mathrm{U}$ Taq DNA polymerase (Vivantis, Malaysia). A total of $32.60 \mu \mathrm{l}$ of molecular grade water (AppliChem) was added to a final volume of $50 \mu \mathrm{l}$. The cycling condition of the rроB PCR assay was performed as described by Stoop et al. [26] and Lehner et al. [27].

Species-specific detection and differentiation of Cronobacter species by Multiplex-PCR (M-PCR) assay employing amplification of the cgcA gene were performed as described earlier [28]. PCR was performed in a reaction volume of $50 \mu \mathrm{L}$ containing $5 \mu \mathrm{L}$ of $10 \times \mathrm{PCR}$ buffer (Vivantis), 4 mM $\mathrm{MgCl}_{2}$ (Vivantis), $0.2 \mathrm{mM}$ dNTP mix (Vivantis), $0.4 \mu \mathrm{M}$ of each primers (Biomers), $5 \mu \mathrm{L}$ of DNA template (50 ng/ $\left.\mu \mathrm{L}\right)$ and $2 \mathrm{U}$ of Taq DNA polymerase (Vivantis). The final volume to $50 \mu \mathrm{L}$ was adjusted by adding molecular grade water (AppliChem). The PCR condition of the $c g c A$ MPCR assays was carried out as described by Carter et al. [28]. The primer sequences, expected size of amplification products and references for both methods are given in Table 3.

\section{Virulence factors of Cronobacter spp.}

a) Detection of the ompA gene

The PCR was targeted to ompA gene, which was previously suggested by Mohan-Nair and Venkitanarayanan [14] (Table 3). Reactions were performed in $50 \mu \mathrm{L}$ volume, $5 \mu \mathrm{L}$ 10x PCR buffer (Vivantis), $2 \mathrm{mM}$ of $\mathrm{MgCl}_{2}$ ( $50 \mathrm{mM}$, Vivantis), $0.2 \mathrm{mM}$ dNTP mix (10 mM, Vivantis), $1 \mu \mathrm{M}$ (each) primer (10 $\mu \mathrm{M}$, Biomers), $1.25 \mathrm{U}$ of Taq DNA polymerase (Vivantis), $3 \mu \mathrm{L}$ of $50 \mathrm{ng}$ (template DNA) and $28.75 \mu \mathrm{L}$ molecular grade water (AppliChem,). PCR cycling conditions for amplification of DNA fragments was performed as described by Mohan-Nair and Venkitanarayanan [14].

b) Detection of the zpx gene

The PCR protocol which amplifies a 94 bp region of the zpx gene was applied to all isolates [13] (Table 3). The PCR amplification of the zpx gene was achieved by $3 \mu \mathrm{L}$ template DNA ( $50 \mathrm{ng} / \mu \mathrm{L})$ with a $47 \mu \mathrm{L}$ of PCR mixture containing the following: $5 \mu \mathrm{L} 10 \times$ PCR buffer (Vivantis), $2 \mu \mathrm{L}$ of 50 $\mathrm{mM} \mathrm{MgCl}_{2}$ (Vivantis), $1 \mu \mathrm{L}$ of $10 \mathrm{mM}$ dNTP mix (Vivantis), $1.25 \mathrm{U}$ Taq DNA polymerase (Vivantis), $5 \mu \mathrm{L}$ from primers (10 $\left.\mu \mathrm{M}, \mathrm{Biomers}\right)$ and 28.75 of molecular grade water (AppliChem). The amplification conditions of the $z p x$ gene were as follows: an initial denaturation of $95^{\circ} \mathrm{C}$ for $15 \mathrm{~s}$, followed by 35 cycles of $94^{\circ} \mathrm{C}$ for $1 \mathrm{~min}, 62^{\circ} \mathrm{C}$ for $1 \mathrm{~min}, 72^{\circ} \mathrm{C}$ for $1 \mathrm{~min}$, with a final elongation at $72^{\circ} \mathrm{C}$ for $10 \mathrm{~min}[13$.

All PCR reactions were carried out on a XP Thermal Cycler (Bioer Technology Co., Ltd., Japan). The PCR products were analyzed in agarose gel (1.5\%) (Merck) and visualized with ultraviolet transilluminator (DNR Minilumi Bio-imaging Systems Ltd., Mahale HaHamisha, Jerusalem, Israel).

c) Siderophore production of Cronobacterspp.

Siderophore production was studied based on the Chrome azurol S (CAS) assay of Schwyn and Neilands [60] with some modifications made by Fiss and Brooks [61]. Briefly, overnight culture of Cronobacter isolates were spot inoculated onto a chrome azurol S (CAS) agar plate and incubated for 5 days at $37^{\circ} \mathrm{C}$. After incubation, siderophore positive isolates were seen as an orange halo around a colony [60].

d) Biofilm formation of Cronobacterspp.

Biofilm formation of the Cronobacter isolates was analyzed using the microtiter plate technique described by Stepanovic et al. [62] and Ye et al. [53] with some modifications. The Cronobacter isolates were incubated in $5 \mathrm{~mL}$ of Tryptic Soy Broth (Merck) at $37^{\circ} \mathrm{C}$ for $24 \mathrm{~h}$. Cultures were diluted until reaching 0.5 on the McFarland scale (approximately $10^{8}$ cells $/ \mathrm{mL}$ ) and $200 \mu \mathrm{L}$ of each suspension were transferred into wells. Following incubation at $37^{\circ} \mathrm{C}$ for $48 \mathrm{~h}$, wells were washed once sterile phosphate-buffered saline ( $\left.\mathrm{pH} 7.2\right)$, fixed with $200 \mu \mathrm{L}$ methanol (Merck). After microplate were stained with crystal violet $200 \mu \mathrm{L}$ of $0.1 \%$ (Merck) for 15 min, dried and resolubilized with $200 \mu \mathrm{L}$ glacial acetic acid (33\% $(\mathrm{v} / \mathrm{v})$ ) (Merck). The optical density (OD) was measured at $570 \mathrm{~nm}$ (Multiskan Ascent spectrophotometer, Thermo Electron Corporation, Vantaa, 
Finland). All the experiments were performed triple times. The isolates were classified as strong, moderate and weak for biofilm formation with respect to Stepanovic et al. [62].

\section{Enterobacterial repetitive intergenic consensus (ERIC)-PCR}

ERIC-PCR was performed using the primer pair, ERIC1R and ERIC2 as described previously by Versalovic et al. [23] (Table 3). PCR reaction was optimized in a $50 \mu \mathrm{L}$ reaction mixture consisting of $3 \mu \mathrm{L}$ of the bacterial genomic DNA solution ( $50 \mathrm{ng}), 5 \mu \mathrm{L}$ of $10 \times$ PCR buffer (Vivantis), $4 \mu \mathrm{L}$ of $50 \mathrm{mM} \mathrm{MgCl} 2$ (Vivantis), $1 \mu \mathrm{L}$ of $10 \mathrm{mM}$ dNTPs (Vivantis), $1 \mu \mathrm{L}$ of $10 \mu \mathrm{M}$ primers (Biomers), $1.25 \mathrm{U}$ Taq polymerase and $34.75 \mu \mathrm{L}$ nuclease free water. ERIC-PCR was performed as follows: $8 \mathrm{~min}$ at $94^{\circ} \mathrm{C}$, followed by 35 cycles of $30 \mathrm{~s}$ at $94^{\circ} \mathrm{C}, 1 \mathrm{~min}$ at $55^{\circ} \mathrm{C}$, and $8 \mathrm{~min}$ at $72^{\circ} \mathrm{C}$, and a final extension at $72^{\circ} \mathrm{C}$ for $10 \mathrm{~min}$. The PCR amplicons were separated on agarose gel (1\%), stained with ethidium bromide and visualized under a UV transilluminator (DNR Minilumi Bio-imaging Systems Ltd., Israel).

\section{Data analysis}

The band patterns generated by ERIC-PCR were analyzed by using the BioNumerics version 7.6 software (Applied Maths, Sint-Martens-Latem, Belgium) based on the Dice's similarity coefficient with a $1 \%$ position tolerance and the unweighted pair group method using arithmetic averages (UPGMA).

\section{Antimicrobial susceptibility test}

All Cronobacterspp. were tested for antimicrobial susceptibility to 18 antimicrobials using the disk diffusion method according to the Clinical and Laboratory Standards Institute [63]. Antibiotic disks (Oxoid, Basingstoke, U.K.) with the following concentrations were used: penicillins (ampicillin- $10 \mu \mathrm{g}$; piperacillin- $100 \mu \mathrm{g}$ ), carbapenems (imipenem- $10 \mu \mathrm{g}$; meropenem- $10 \mu \mathrm{g}$ ), $\beta$-lactamase inhibitors (amoxicillin-clavulanic acid$30 \mu \mathrm{g}$; piperacillin-tazobactam- $110 \mu \mathrm{g}$ ), cephalosporins (cefotaxime- $30 \mu \mathrm{g}$; cefoxitin- $30 \mu \mathrm{g}$; cephalothin- $30 \mu \mathrm{g}$; cefepime- $30 \mu \mathrm{g}$ ), aminoglycosides (gentamicin- $10 \mu \mathrm{g}$; amikacin- $30 \mu \mathrm{g}$ ), tetracyclines (tetracycline- $30 \mu \mathrm{g}$ ), folate pathway inhibitors (trimethoprim/sulfamethoxazole- $25 \mu \mathrm{g}$ ), monobactam (aztreonam- $30 \mu \mathrm{g}$ ), quinolones (nalidixic acid- $30 \mu \mathrm{g}$; ciprofloxacin- $5 \mu \mathrm{g}$ ) and phenicols (chloramphenicol- $30 \mu \mathrm{g}$ ). The results of all the inhibition zones of antimicrobial agents were interpreted according to Enterobacteriaceae table in CLSI [63].

\section{Results}

\section{Isolation and identification of Cronobacterspp.}

Out of the 340 ready-to-eat foods tested, phenotypically, a total of $17.4 \%$ (59/340) of samples, categorized as $51.9 \%$ (14/27) of meat free cig koftes, $46.7 \%(7 / 15)$ of spices, $30.8 \%$ (4/13) of cereals, $30.2 \%$ (13/43) of desserts, $14.8 \%(4 / 27)$ of ice creams, $12.2 \%(6 / 49)$ of doners, $9.8 \%$ (4/41) of pastramis, $8.6 \%(3 / 35)$ of kavurmas, $7.5 \%$ (3/40) of cheeses and $2.6 \%(1 / 38)$ of salads were considered contaminated with Cronobacter species. Cronobacter spp. were not detected in herbs and vegetables. Of the 59 contaminated samples, the 54 samples contained only one species, whereas 5 samples contained two different species. Thus, the 64 isolates were identified. The occurrence of Cronobacter isolates in the 59 ready-to-eat food samples analyzed is summarized in Table 1.

In this study, all phenotypically-identified isolates were completely confirmed by the genus-specific $16 \mathrm{~S}$ rRNA gene while the presence of $g / u A$ gene was $93.8 \%$ among the Cronobacter isolates. All Cronobacter species differentiated using species-specific the $r p o B$ gene and the $c g c A$ gene along with the results of the biochemical identification, the 16S rRNA and gluA are shown in Table 2.

\section{Virulence characteristics of Cronobacterspp.}

The pathogenic potential of the obtained Cronobacter isolates was confirmed by the presence of virulence related genes: ompA is associated with the invasion ability; zpx encodes the zinc-containing metalloprotease that contributes pathogenicity of Cronobacter. All 64 Cronobacter isolates (100\%) were found to be positive for the ompA gene while $63(98.4 \%)$ isolates harbored the zpx gene. The biofilm formation was detected in the $56(87.5 \%)$ of the 64 isolates by the microtiter plate assay. Overall, $3.1 \%, 31.3 \%$ and $53.1 \%$ of the Cronobacter isolates were strong, moderate and weak biofilm producer, respectively. On the other hand, the production of siderophore as a significant virulence property was detected in all Cronobacterisolates (100\%) (Table 2).

\section{Genetic variation among the Cronobacterisolates from ready-to-eat foods}

The 64 Cronobacter isolates and type strain C. sakazakii ATCC 29544 were subjected to ERIC-PCR. All isolates amplified with the ERIC primers. The ERIC-PCR generated the 3 to 12 amplified bands with sizes ranging from 100 to $3000 \mathrm{bp}$. We identified 64 different ERIC patterns with a similarity index ranging from $10 \%$ to $100 \%$ using the BioNumerics software (version 7.6) (Fig. 1). The ERIC patterns were grouped into two major clusters (A and B). The predominant cluster was cluster B, which contained $56(86.2 \%)$ isolates, 2 of which had the same pattern. Cluster A was 
composed of $9(13.8 \%)$ of the isolates that presented 9 distinct patterns. The Cronobacter isolates from the same food categories were represented in the distinct patterns; therefore, there was no correlation between the ERIC-PCR profiles and origin of the isolates (Fig. 1).

\section{Antimicrobial resistance}

The antimicrobial susceptibility results of all 64 Cronobacter isolates from RTE food to 18 antimicrobial agents interpreted as susceptible, intermediate or resistant are shown in Fig. 2. All Cronobacter isolates were susceptible to trimethoprim/sulfamethoxazole and gentamicin. The most frequently detected resistances were to cephalothin (81.3\%), followed by cefoxitin (32.8\%), and ampicillin (20.3\%). The profiles of multidrug resistance were detected in $12(18.8 \%)$ of the Cronobacter isolates to at least three or more antimicrobial agents. The antimicrobial resistances and intermediate results for each of the 64 isolates are exhibited in Table 2.

\section{Discussion}

Cronobacter species as pathogens cause severe infections in vulnerable adults and infants. These bacteria which are ubiquitous have been isolated from a wide range of sources such as contaminated ready-to-eat foods [5, 6, 34]. In this study, the prevalence of Cronobacter spp. in RTE foods was detected to be $17.4 \%$. In previous studies, the level of contamination with Cronobacter spp. in RTE foods ranged from $9.0 \%$ to $45 \%$ [4, 37-39]. The different rates of the presence of the Cronobacter in various foods have been documented in many different countries such as in Ireland, China, India, Brazil and Egypt [9, 40-42]. The variation in the occurrence of bacteria can be explained by different factors such as source of the isolation, nature of samples and geographic location [5].

In recent studies, among food products, cereal, flour, pasta, herbs and spices have been highlighted as being most frequently contaminated by Cronobacter spp. $[9,38,41]$. In the current study, Cronobacter spp. were commonly isolated from $51.9 \%, 46.7 \%, 30.8 \%$ and $30.2 \%$ samples of meat-free cigkoftes, spices, cereals and desserts, respectively. In Turkey, meat-free cig kofte is a popular food consisting of bulgur, various spices and vegetables and it is consumed uncooked. In particular, a high occurrence of Cronobacterspp. (51.9\%) in meat free cig koftes may be due to contaminated ingredients including cereal (46.7\%) and spices (30.8\%). In the study of Aksu et al. [10] in Turkey, the 50\% of the Cronobacter isolates obtained from cig kofte (cereal-based ball) was similar to our research. Four samples of cereals (bulgur, red lentil, peanut, and goji berry) and seven samples of spices (cumin, chili pepper, thyme, mint, flower flour, coconut) were contaminated with Cronobacter spp. (Table 1). These findings were similar to some studies focused on isolation from cereals and spices [38, 40, 41]. The reported isolation rates of Cronobacter spp. in cereal samples varied from $4.9 \%$ to $45 \%[40,41,43]$, while in spices samples varied from $3.6 \%$ to $34 \%$ [37, 41, 43].

In several studies, Cronobacterwere isolated from flours and dairy products such as milk-based desserts, cheeses, raw milk, curd, ice-cream [38, 41-43]. In this study, Cronobacter spp. were detected from desserts including milky desserts (2/16) and dough sweets (11/27) (Table 1). Desserts can be made by using ingredients such as milk, flour, cream, flavors, sweeteners, cereals, nuts and fruits. Our study indicates that contamination of desserts may be resulted from contaminated ingredients. In the study of Saad and Ewida [42], the prevalence of Cronobacterspp. was detected in $5.5 \%$ of milk-based desserts in accordance with the result of our study. The occurrence of Cronobacter in cheeses (7.5\%) was found to be higher than results of studies of Iversen and Forsythe [44] and Singh et al. [41]. In another study, Cronobacter was not isolated (0/20) from cheeses [40]. Saad and Ewida [42] isolated Cronobacterfrom 1/30 samples of ice-cream, but Kandhai et al. [43] did not found Cronobacterin icecream (0/89). These findings were lower than our results $(14.8 \%)$ in ice-cream samples.

The occurrence of Cronobacter spp. was $12.2 \%$ in doner, $9.8 \%$ in pastramis and $8.6 \%$ in kavurmas as retail meat products in this research. Several studies demonstrated varying prevalence of Cronobacter spp.in meat and meat products: $0.0 \%$ in Turkey [10], 3.2\% in the Netherlands [43], and $14.5 \%$ in China [4]. In this study, Cronobacter spp. were isolated from $2.6 \%$ samples of salads, while were not detected in herbs and vegetables. The result in salads (1/38) was lower than the result (13/30) obtained by Vasconcellos et al. [39], while was similar to the result (1/15) obtained by Lee et al. [45]. Cronobacter were not detected from dried herbs and vegetables in some studies, similar to our results [10, 40]. In another research, the Cronobacter spp. was detected in $25 \%$ of vegetables [41]. In the light of our results and results of many previous studies, it has been considered that the contamination of RTE foods may be the result from the contaminated ingredients, improper food handling practices, storage conditions and environmental factors.

In the present study, all Cronobacterspp. to the genus level were identified using the 16S rRNA and the gluA gene. Many researchers have been used the gluA gene as an additional tool for identification of Cronobacter spp. [24, 46]. Iversen et al. [46] reported that g/uA gene were 100\% sensitive and specific for determination and confirmation of Cronobacter spp. However, in this research, out of the 64 isolates, the 60 (93.8\%) isolates were positive for the gluA gene (Table 2). Some other researchers did not also detect the gluA gene in some of Cronobacter strains, similar to our findings $[47,48]$.

In this study, in addition to phenotypic identification, the genotypic identification of Cronobacterisolates were performed using the speciesspecific $r p o B$ and $c g c A$ genes [26-28]. Although the Cronobacter isolates were completely identified by the biochemical test and the $r p o B$ PCR method, the eight isolates were not identified by the $c g c A$ M-PCR method. Compared to the results of identification using the $r p o B$ gene, failure results in the $c g c A$ method were associated with the species $C$. malonaticus, $C$. turicensis, $C$. muytjensii and $C$. dublinensis (Table 2 ). Of 64 
Cronobacter isolates, 42 (65.6\%) were completely consistent according to the identification results of the biochemical tests, rpoB PCR method and $c g c A$ M-PCR method. Among the remaining Cronobacter isolates, there was inconsistency to phenotypic and genotypic identification methods. In this study, the identification of 41 C. sakazakii isolates was same in rpoB PCR and $c g c A$ M-PCR method. Brandao et al. [38] identified successfully Cronobacterisolates to the species level using $c g c A$ primers. However, some reports documented the inefficiency of $c g c A$ gene to identify some Cronobacter isolates for the species-specific identification [30, 39].

C. sakazakii is most common among the species of the Cronobacter genus and plays a significant role in human diseases [5, 20]. In this study, $C$. sakazakii was also the most common Cronobacter species isolated, followed by C. malonaticus and other species of Cronobacter. Many researchers found $C$. sakazakii as the most common species among the Cronobacter genus, similar to our result [10, 30, 38]. Moreover, in many previous studies, the $C$. malonaticus andother species of Cronobacter were isolated from various foods $[4,30,39]$.

In the present study, various virulence characteristics such as outer membrane protein A (OmpA), zinc-containing metalloprotease, siderophore production, and biofilm formation were found among Cronobacter isolates from RTE foods. The ompA gene encoding OmpA, has a significant role in Cronobacterinvasion, was detected in $100 \%$ of the Cronobacter isolates. Similarly, the occurrence of ompA gene was found $100 \%$ among the Cronobacter isolates by many researchers $[43,49]$. On the contrary, in some studies, the incidence of Cronobacter spp. containing the ompA gene has been reported as $64.7 \%$ in the USA [50] and 33.3\% in the Bangladesh[17]. In addition, in this study, many isolates of Cronobacter (98.4\%) harbored the $z p x$ gene encoding zinc-containing metalloprotease as an indicator of pathogenicity. The prevalence of $z p x$ gene in Cronobacter spp. ranging from $1.3 \%$ to $65.5 \%$ was reported in previous studies $[17,47,51]$. Siderophore required for the iron uptake is a virulence factor for Cronobacter [19]. In several researches, all Cronobacter isolates exhibited siderophore production, similar to the result in this research $[17,52]$. Biofilms are considered to be a potential way of pathogen transmission $[17,18]$. In this study, the biofilm formation of Cronobacter (87.5\%) was higher than the result obtained by Fakruddin et al. [17] and Lee et al. [45], while was similar to the result obtained by Ye et al. [53]

The genetic diversity of the 64 Cronobacter isolates in RTE food products and type strain C. sakazakii ATCC 29544 was assessed by ERIC-PCR in the present research (Fig. 1). The 64 distinct ERIC-PCR profiles were categorized in two major clusters (A and B) at a similarity threshold of $10 \%$. Most isolates (>86\%) harbored virulence factors and antibiotic resistance were distributed on the cluster B. In this study, the results of ERIC-PCR indicated that there was no apparent clustering tendency among the genotypes related to the origin of isolates, virulence profile and antimicrobial resistance. In many studies, genetic variation of Cronobacter isolates from various food samples have been also detected using ERIC-PCR method $[17,54,55]$.

In this study, the resistance rates of the Cronobacter isolates ranging from $1.5 \%$ to $20.3 \%$ to piperacillin, ampicillin, amoxicillin-clavulanic acid, nalidixic acid, aztreonam were obtained. Previous reports revealed the occurrence of resistance to the antimicrobial agents in Cronobacter spp. isolated from different sources [31, 32, 56]. Increasing resistance of Cronobacter against a range of cephalosporins and penicillins due to the production of $\beta$-lactamases has been reported $[11,29,30]$. In our study, the cephalosporins that are used in the treatment of Cronobacter infections had resistance ranging from $4.7 \%$ to $81.3 \%$ through the first- second- third- fourth generation. In addition, in the present study, it is noteworthy that Cronobacter isolates displayed a high intermediate resistance to cefoxitin (32.8\%), cefepime (21.9\%), cefotaxime (20.3\%), ampicillin (17.2\%), piperacillin (17.2\%) and cephalothin (10.9\%) (Fig. 2). In several studies, the resistance to ampicillin, cephalothin, cefoxitin, and cefotaxime in Cronobacter was reported to range from 5.6\% to 50.0\% [31, 32]. Cronobacter infections have been treated with carbapenems or the newer cephalosporins in concert with an aminoglycoside or trimethoprim-sulfamethoxazole [11, 12]. As prescribed for the treatment, in our study, more than $90 \%$ of the Cronobacter isolates were also susceptibility to piperacillin-tazobactam, gentamicin, amikacin, imipenem, meropenem, tetracycline, trimethoprim/sulfamethoxazole, ciprofloxacin, and chloramphenicol. Susceptibility to these antimicrobials has been reported in many countries: Brazil [30], China [9], and Iran [56]. In the current study, the multidrug resistance to at least three or more antimicrobial agents was detected in the 12 (18.8\%) of Cronobacterisolates. The findings of Kim et al. [57] and Li et al. [58] were contrary to our results that any isolates were resistant against three or more antimicrobial agents.

\section{Conclusions}

Cronobacter spp. were isolated from samples of ready-to-eat (RTE) foods, with a higher presence of $C$. sakazakii, an emerging foodborne pathogen. The present study provides current knowledge on the incidence, identification, genotyping, potential virulence and antimicrobial resistance of Cronobacter spp. in RTE foods. The consumption of RTE foods contaminated with antimicrobial resistant or potential pathogenic Cronobacter may cause a serious threat to human health especially for children, elderly and immunocompromised people. As a result, RTE foods may be a possible transmission vehicle for Cronobacterinfection in vulnerable person, and need adoption of hygienic practices and rigorous sanitization treatments to ensure microbiological safety.

\section{Abbreviations}

BPW: Buffered peptone water; CAS: Chrome azurol S; CLSI: Clinical and Laboratory Standards Institute; ERIC-PCR: Enterobacterial repetitive intergenic consensus-PCR; FDA: Food and Drug Administration; ICMSF: International Commission for Microbiological Specifications for Foods;

Page $7 / 18$ 
ISO: International Organization for Standardization; MLST: Multilocus sequence typing; M-PCR: Multiplex-PCR; OD: Optical density; OmpA: Outer membrane protein A; PFGE: Pulsed-field gel electrophoresis; RTE: Ready-to-eat; TSA: Tryptic Soy Agar; UPGMA: Unweighted pair group method with arithmetic mean; VRBG: Violet Red Bile Glucose; VRBL: Violet Red Bile Lactose

\section{Declarations}

\section{Authors' contributions}

SA designed the study and analyzed the data. SA revised the manuscript. HGE performed the experiments and interpretation of the results and wrote the draft. All authors read and approved the final manuscript.

\section{Availability of data and materials}

All data generated or analyzed during this study are included in this published article and its supplementary information files.

\section{Ethics approval and consent to participate}

Not applicable.

\section{Consent for publication}

Not applicable.

\section{Competing interests}

The authors declare that they have no competing interests.

\section{References}

1. Iversen C, Lehner A, Mullane N, Bidlas E, Cleenwerck I, Marugg J, Fanning S, Stephan R, Joosten H. The taxonomy of Enterobacter sakazakii: proposal of a new genus Cronobacter gen. nov. and descriptions of Cronobacter sakazakii comb. nov. Cronobacter sakazakii subsp. sakazakii, comb. nov., Cronobacter sakazakii subsp. malonaticus subsp. nov., Cronobacter turicensis sp. nov., Cronobacter muytjensii sp. nov., Cronobacter dublinensis sp. nov. and Cronobacter genomospecies 1. BMC Evol Biol. 2007;7:64.

2. Iversen C, Mullane N, McCardell B, Tall BD, Lehner A, Fanning S, Stephan R, Joosten H. Cronobacter gen. nov., a new genus to accommodate the biogroups of Enterobacter sakazakii, and proposal of Cronobacter sakazakii gen. nov., comb. nov., Cronobacter malonaticus sp. nov., Cronobacter turicensis sp. nov., Cronobacter muytjensii sp. nov., Cronobacter dublinensis sp. nov., Cronobacter genomospecies 1 , and of three subspecies, Cronobacter dublinensis subsp. dublinensis subsp. nov., Cronobacter dublinensis subsp. lausannensis subsp. nov. and Cronobacter dublinensis subsp. lactaridi subsp. nov. Int J Syst Evol Microbiol. 2008;58:1442-1447.

3. Joseph S, Cetinkaya E, Drahovske H, Levican A, Figueras MJ, Forsythe SJ. Cronobacter condiment sp. nov., isolated from spiced meat and Cronobacter universalis sp.nov., a novel species designation for Cronobacter sp. genomospecies 1, recovered from a leg infection, water, and food ingredients. Int J Syst Evol Microbiol. 2012;62:1277-1283.

4. Xu X, Li C, Qingping W, Zhang J, Huang J, Yang G. Prevalence, molecular characterization, and antibiotic susceptibility of Cronobacter spp. in Chinese ready-to-eat foods. Int J Food Microbiol. 2015;204:17-23.

5. Forsythe SJ. Updates on the Cronobacter Genus. Annu Rev Food Sci T. 2018;9:23-44.

6. Farmer JJ, Asbury MA, Hickman FW, Brenner DJ. Enterobacter sakazakii: A new species of "Enterobacteriaceae" isolated from clinical specimens. Int J Syst Evol Micr.1980;30(3):569-584.

7. ICMSF (International Commission on Microbiological Specifications for Foods). Microorganisms in Foods 7: Microbiological Testing in Food Safety Management. New York: Kluwer Academic \& Plenum Publishers; 2002.

8. Holy O, Forsythe S. Cronobacter spp. as emerging causes of healthcare-associated infection. J Hosp Infect. 2014;86:169-177.

9. Li Y, Chen Q, Zhao J, Jiang H, Lu F, Bie X, Lu Z. Isolation, identification and antimicrobial resistance of Cronobacter spp. isolated from various foods in China. Food Control. 2014;37:109-114.

10. Aksu F, Altunatmaz SS, Issa G, Aksoy A, Aksu H. Prevalence of Cronobacter spp. in various foodstuffs and identification by multiplex PCR. Food Sci. Technol. 2018; doi: https://doi.org/10.1590/fst.06818. 
11. Lai KK. Enterobacter sakazakii infections among neonates, infants, children, and adults. Case reports and a review of the literature. Medicine (Baltimore). 2001;80:113-122.

12. Jaradat ZW, Mousa WA, Elbetieha A, Nabulsi AA, Tall BD. Cronobacter spp.- opportunistic food-borne pathogens. A review of their virulence and environmental-adaptive traits. J. Med. Microbiol. 2014;63,1023-1037.

13. Kothary MH, McCardell BA, Frazar CD, Deer D, Tall BD. Characterization of the Zinc-Containing Metalloprotease Encoded by zpx and Development of a Species-Specific Detection Method for Enterobacter sakazakii. Appl Environ Microbiol. 2007;73:4142-4151.

14. Mohan Nair MK, Venkitanarayanan KS. Cloning and Sequencing of the ompA Gene of Enterobacter sakazakii and Development of an ompATargeted PCR for Rapid Detection of Enterobacter sakazakii in Infant Formula. Appl Environ Microbiol. 2006;72:2539-2546.

15. Kim K, Kim KP, Choi J, Lim JA, Lee J, Hwang S, Ryu S. Outer membrane proteins A (OmpA) and X (OmpX) are essential for basolateral invasion of Cronobacter sakazakii. Appl Environ Microbiol. 2010;76:5188-5198.

16. Mittal R, Wang Y, Hunter CJ, Gonzalez-Gomez I, Prasa-darao NV. Brain damage in newborn rat model of meningitis by Enterobacter sakazakii: A role for outer membrane protein A. Lab Invest. 2009;89:263-277.

17. Fakruddin M, Rahaman M, Ahmed MM, Hoque MM. Stress tolerant virulent strains of Cronobacter sakazakii from food. J Biol Res. 2014;47:63.

18. Lehner A, Riedel K, Eberl, L, Breeuwer P, Diep B, Stephan A. Biofilm formation, extracellular polysaccharide production, and cell-to-cell signaling in various Enterobacter sakazakii strains: aspects promoting environmental persistence. J Food Prot. 2005;68:2287-2294.

19. Grim CJ, Kothary MH, Gopinath G, Jarvis KG, Beaubrun JJG, McClelland M, Tall BD, Francoa AA. Identification and Characterization of Cronobacter Iron Acquisition Systems. Appl Environ Microbiol. 2012;78:6035-6050.

20. Muytjens HL, Roelofs-Willemse H, Jaspar GH. Quality of powdered substitutes for breast milk with regard to members of the family Enterobacteriaceae. J Clin Microbiol. 1988;26:743-746.

21. Food and Drug Administration: Center for Food Safety and Applied Nutrition. Isolation and enumeration of Enterobacter sakazakii from dehydrated powdered infant formula. 2007. http://www.cfsan.fda.gov/-comm/mmesakaz.html. Accessed 25 May 2007.

22. International Organization for Standardization. Milk and milk products-detection of Enterobacter sakazakii. Technical specification ISO/TS 22964:2006(E) and IDF/RM 210:2006(E). 1st ed. Switzerland: Geneva; 2006.

23. Versalovic J, Koeuth T, Lupski JR. Distribution of repetitive DNA sequences in eubacteria and application to fingerprinting of bacterial genomes. Nucleic Acids Res. 1991;19(24):6823-6831.

24. Lehner, A, Nitzsche S, Breeuwer P, Diep B, Thelen K, Stephan R. Comparison of two chromogenic media and evaluation of two molecular based identification systems for Enterobacter sakazakii detection. BMC Microbiol. 2006;6:15.

25. Hassan AA, Akineden Ö, Kress C, Estuningsih S, Schneider E, Usleber E. Characterization of the gene encoding the 16S rRNA of Enterobacter sakazakii and development of a species-specific PCR method. Int J Food Microbiol. 2007;116:214-220.

26. Stoop B, Lehner A, Iversen C, Fanning S, Stephan R. Development and evaluation of rpoB based PCR systems to differentiate the six proposed species within the genus Cronobacter. Int J Food Microbiol. 2009;136:165-168.

27. Lehner A, Fricker-Feer C, Stephan R. Identification of the recently described Cronobacter condimenti by an rpoB-gene-based PCR system. J Med Microbiol. 2012;1034-1035.

28. Carter L, Lindsey LA, Grim CJ, Sathyamoorthy V, Jarvis KG, Gopinath G, Lee C, Sadowski JA, Trach L, Pava-Ripoll M, McCardell BA, Tall BD, Hu L. Multiplex PCR assay targeting a diguanylate cyclase-encoding gene, cgcA, to differentiate species within the genus Cronobacter. Appl Environ Microbiol. 2013;79(2):734-737.

29. Stock I, Wiedemann B. Natural antibiotic susceptibility of Enterobacter amnigenus, Enterobacter cancerogenus, Enterobacter gergoviae and Enterobacter sakazakii strains. Clin Microbiol Infec. 2002;8:564-578.

30. Silva JN, Vasconcellos L, Forsythe SJ, Filippis I, Brandao MLL. Molecular and phenotypical characterization of Cronobacter species isolated with high occurrence from oats and linseeds. FEMS Microbiol Lett. 2019;366:1-6. 
31. Kilonzo-Nthenge A, Rotich E, Godwin S, Nahashon S, Chen F. Prevalence and antimicrobial resistance of Cronobacter sakazakii isolated from domestic kitchens in middle Tennessee, United States. J Food Prot. 2012;75(8):1512-1517.

32. Yao K, N'guessan KF, Zinzendorf NY, Kouassi KA, Kouassi KC, Loukou YG, Kouame PL. Isolation and characterization of Cronobacter spp. from indigenous infant flours sold in public health care centres within Abidjan, Côte d'Ivoire. Food Control. 2016;62:224-230.

33. Buckley M, Cowana C, McCarthy M. The convenience food market in Great Britain: Convenience food lifestyle (CFL) segments. Appetite. 2007;49: 600-617.

34. WHO. Food and Health in Europe: a new basis for action. WHO regional publications European Series; 2004.

35. Gökmen M, Tekinşen KK, Gürbüz Ü. Presence of Enterobacter sakazakii in Milk Powder, Whey Powder and White Cheese Produced in Konya. Kafkas Univ Vet Fak Derg. 2010;16(Suppl-A):S163-S166.

36. Gümüş PC, Tekiner IH, Çakmak B, Caba ZT, Özpinar H. Investigation of Extended Spectrum B-Lactamases (ESBL)-Producing

Enterobacteriaceae and Cronobacter spp. in Infant Formulas and Cereal-Based Foods for Children. IGUSABDER, 2017;1:19-32.

37. Baumgartner A, Grand M, Liniger M, Iversen C. Detection and frequency of Cronobacter spp. (Enterobacter sakazakii) in different categories of ready-to-eat foods other than infant Formula. Int J Food Microbiol. 2009;136:189-192.

38. Brandao MLL, Umeda NS, Jackson E, Forsythe SJ, Filippis I. Isolation, molecular and phenotypic characterization, and antibiotic susceptibility of Cronobacterspp. from Brazilian retail foods. Food Microbiol. 2017;63:129-138.

39. Vasconcellos L, Carvalho CT, Tavares RO, Medeirosa VM, Rosasa CO, Silva JN, Lopesa SMR, Forsythe SJ, Brandao MLL. Isolation, molecular and phenotypic characterization of Cronobacter spp. in ready-to-eat salads and foods from Japanese cuisine commercialized in Brazil. Food Res Int. 2018;107:353-359.

40. Molloy C, Cagney C, O’Brien S, Iversen C, Fanning S, Duffy G. Surveillance and characterisation by Pulsed-Field Gel Electrophoresis of Cronobacter spp. in farming and domestic environment, food production animals and retail foods. Int J Food Microbiol. 2009;136:198-203.

41. Singh N, Goel G, Raghav M. Insights into virulence factors determining the pathogenicity of Cronobacter sakazakii. Virulence. 2015;6(5):433440 .

42. Saad NM, Ewida RM. Incidence of Cronobacter sakazakii in Dairy-based Desserts. J Adv Vet Res. 2018;8:16-18.

43. Kandhai MC, Heuvelink AE, Reij MW, Beumer RR, Dijk R, van Tilburg JJHC, van Schothorst M, Gorris LGM. A study into the occurrence of Cronobacter spp. in The Netherlands between 2001 and 2005. Food Control. 2010;21:1127-1136.

44. Iversen C, Forsythe S. Isolation of Enterobacter sakazakii and other Enterobacteriaceae from powdered infant formula milk and related products. Food Microbiol. 2004;21:771-777.

45. Lee YD, Parka JH, Chang H. Detection, antibiotic susceptibility and biofilm formation of Cronobacter spp. from various foods in Korea. Food Control. 2012;24:225-230.

46. Iversen C, Lehner A, Mullane N, Marugg J, Fanning S, Stephan R, Joosten Han. Identification of “Cronobacter" spp. (Enterobacter sakazakii). J Clin Microbiol. 2007;45(11):3814-3816.

47. Jaradat ZW, Ababneh QO, Saadoun IM, Samara NA, Rashdan AM. Isolation of Cronobacter spp. (formerly Enterobacter sakazakii) from infant food, herbs and environmental samples and the subsequent identification and confirmation of the isolates using biochemical, chromogenic assays, PCR and 16S rRNA sequencing. BMC Microbiol. 2009;9:225.

48. Mofokeng L, Cawthorn DM, Witthuhn RC, Anelich LECM and Jooste PJ. Characterization of Cronobacter species (Enterobacter sakazakii) isolated from various south African food sources. J Food Saf. 2010;31:98-107.

49. Holy O, Cruz-Cordova A, Xicohtencatl-Cortes J, Hochel I, Parra-Flores J, Petrzelova J, Facevicova K., Forsythe S, Alsonosi A. Occurrence of virulence factors in Cronobacter sakazakii and Cronobacter malonaticus originated from clinical samples. Microb Pathog. 2019;127:250-256.

50. Yan X, Gurtler J, Fratamico P, Hu J, Gunther NW, Juneja V, Huang L. Comprehensive Approaches to Molecular Biomarker Discovery for Detection and Identification of Cronobacter spp. (Enterobacter sakazakii) and Salmonella spp. Appl Environ Microbiol. 2011;77(5):1833-1843.

51. Awadallah MAl, Ahmed HA, Merwad AMA, Abou ERMM, Saleh KMA. Molecular Characterization of Cronobacter sakazakii in Egypt, Survival and Thermoresistance at Different Temperatures: A Potential Public Health Risk. Vector-Borne Zoonot. 2018;18(2):101-107.

Page 10/18 
52. Schmid M, Iversen C, Gontia I, Stephan R, Hofmann A, Hartmann A, Jha B, Eberl L, Riedel K, Lehner A. Evidence for a plant-associated natural habitat for Cronobacter spp. Res Microbiol. 2009;160:608-614.

53. Ye Y, Ling N, Jiao R, Wu Q, Han Y, Gao J. Effects of culture conditions on the biofilm formation of Cronobacter sakazakii strains and distribution of genes involved in biofilm formation. J. Food Sci. Technol. 2015;62:1-6.

54. Ye Y, Wu Q, Xu X, Yang X, Dong X, Zhang J. The phenotypic and genotypic characterization of Enterobacter sakazakii strains from infant formula milk. J. Dairy. 2010;93:2315-2320.

55. Chen W, Ai L, Yang J, Ren J, Li Y, Guo B. Molecular Typing of Cronobacter Strains from Food in China by Enterobacterial Repetitive Intergenic Consensus Sequence PCR (ERIC-PCR) and Sequence Analysis of the gyrB Gene. J Food Saf. 2013;33(4):405-412.

56. Mardaneh J, Dallal MMS. Study of Cronobacter sakazakii Strains Isolated from Powdered Milk Infant Formula by Phenotypic and Molecular Methods in Iran. Arch Pediatr Infect Dis. 2017;5(1):e38867.

57. Kim K, Jang SS, Kim SK, Park JH, Heu S, Ryu S. Prevalence and genetic diversity of Enterobacter sakazakii in ingredients of infant foods. Int J Food Microbiol. 2008;122:196-203.

58. Li Y, Yu H, Jiang H, Jiao Y, Zhang Y, Shao J. Genetic Diversity, Antimicrobial Susceptibility, and Biofilm Formation of Cronobacter spp. Recovered from Spices and Cereals. Front Microbiol. 2017;8:2567.

59. Ausubel FM, Kingston RE, Brent R, Moore DD, Seidman J, Smith JA, Struhl K. Current protocol in molecular biology. New York: Grene Publishing Associates and Wiley Interscience; 1991.

60. Schwyn B, Neilands JB. Universal Chemical Assay for the Detection and Determination of Siderophores. Anal. Biochem. 1986;160:47-56.

61. Fiss E, Brooks GF. Use of a Siderophore Detection Medium, Ethylene Glycol Degradation, and $\beta$-Galactosidase Activity in the Early Presumptive Differentiation of Nocardia, Rhodococcus, Streptomyces, and Rapidly Growing Mycobacterium Species. J Clin Microbiol. 1991;29:1533-1535.

62. Stepanovic S, Vukovic D, Dakic I, Savic B, Svabic-Vlahovic M. A modified microtiter-plate test for quantification of staphylococcal biofilm formation. J Microbiol Meth. 2000;40:175-179.

63. CLSI. Performance standards for antimicrobial susceptibility testing, 24th informational supplement (M100-S24). Wayne: Clinical and Laboratory Standards Institute; 2014.

\section{Tables}

Table 1 Prevalence of the Cronobacter spp. among ready-to-eat foods 


\begin{tabular}{|c|c|c|c|c|}
\hline Samples & $\begin{array}{l}\text { Number of } \\
\text { samples }\end{array}$ & $\begin{array}{c}\text { Number of } \\
\text { contaminated } \\
\text { samples }\end{array}$ & $\begin{array}{l}\text { Percentage of samples contaminated } \\
\text { with Cronobacter spp. }\end{array}$ & Number of Cronobacter isolates \\
\hline \multicolumn{5}{|l|}{ Doners $(n=49)$} \\
\hline Chicken & 28 & 1 & \multirow[t]{2}{*}{$12.2(6 / 49)$} & $1(\mathrm{DN}-3)$ \\
\hline Beef & 21 & 5 & & 6 (DN-1, DN-2, DN-4, DN-5, DN-6, DN-7) \\
\hline Pastramis & 41 & 4 & $9.8(4 / 41)$ & 4 (PS-1, PS-2, PS-3, PS-4) \\
\hline Cheeses & 40 & 3 & $7.5(3 / 40)$ & $3(\mathrm{P}-1, \mathrm{P}-2, \mathrm{P}-3)$ \\
\hline Kavurmas & 35 & 3 & $8.6(3 / 35)$ & 3 (KV-1, KV-2, KV-3) \\
\hline Meat-free cigkoftes & 27 & 14 & $51.9(14 / 27)$ & 15 (CK-1 to CK-15) \\
\hline \multicolumn{5}{|l|}{ Vegetables $(n=5)$} \\
\hline lettuce & 1 & 0 & \multirow[t]{5}{*}{$0.0(0 / 5)$} & 0 \\
\hline pepper & 1 & 0 & & 0 \\
\hline dill & 1 & 0 & & 0 \\
\hline fresh mint & 1 & 0 & & 0 \\
\hline parsley & 1 & 0 & & 0 \\
\hline \multicolumn{5}{|l|}{ Salads $(n=38)$} \\
\hline $\begin{array}{l}\text { Salads (vegetables } \\
\text { and sauces) }\end{array}$ & 28 & 1 & $2.6(1 / 38)$ & 1 (SL-1) \\
\hline $\begin{array}{l}\text { Salads (meat, } \\
\text { cereals, or dough) }\end{array}$ & 10 & 0 & & 0 \\
\hline
\end{tabular}

\section{Desserts $(n=43)$}

Milky desserts

$\begin{array}{lcc}16 & 2 & 30.2(13 / 43) \\ 27 & 11\end{array}$

12 (TT-1, TT-2, TT-3, TT-4, TT-5, TT-7, TT-8, TT-

Dough sweets

9,TT-10, TT-11, TT-12, TT-13)

\section{Spices $(n=15)$}

\begin{tabular}{lll} 
cumin & 2 & 1 \\
chili pepper & 2 & 1 \\
\hline thyme & 1 & 1 \\
\hline turmeric & 1 & 0 \\
\hline ginger & 1 & 0 \\
\hline mint & 2 & 2 \\
\hline black pepper & 1 & 0 \\
\hline cinnamon & 1 & 0 \\
\hline flower flour & 1 & 1 \\
\hline flaxseed & 1 & 0 \\
\hline sesame & 1 & 0 \\
\hline coconut & 1 & 1 \\
\hline
\end{tabular}

$30.8(4 / 13)$

2 (B-1, B-2)

1 (B-5)

1 (B-3)

0

2 (B-4, B-8)

0

0

1 (B-6)

0

0

1 (B-7)

\section{Cereals $(n=13)$}

\begin{tabular}{l} 
rice \\
wheat \\
red lentil \\
bulgur \\
\hline cashew nut \\
peanut \\
hazelnut \\
raisins \\
\hline dried apricot \\
oleaster \\
goji berry
\end{tabular}

1
1
1
1
1
3
1
1
1
1
1

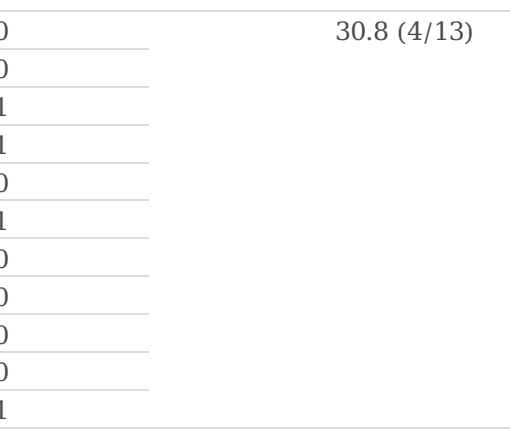

$14.8(4 / 27)$

2 (D-1, D-2)

0

1 (D-3)

2 (D-4, D-5)

Ice creams $(\mathrm{n}=27)$

vanilla

50

fruity

6

2
0
1

0
0
$1(\mathrm{C}-1)$
$1(\mathrm{C}-2)$
0
$1(\mathrm{C}-3)$
0
0
0
0
$1(\mathrm{C}-4)$

Herbs $(n=7)$ 


\begin{tabular}{|c|c|c|c|c|}
\hline sage & 2 & 0 & \multirow[t]{5}{*}{$0.0(0 / 7)$} & 0 \\
\hline licorice & 1 & 0 & & 0 \\
\hline rosehip & 1 & 0 & & 0 \\
\hline linden & 1 & 0 & & 0 \\
\hline black tea & 2 & 0 & & 0 \\
\hline Total & 340 & 59 & $17.4(59 / 340)$ & 64 \\
\hline
\end{tabular}

Table 2 Molecular characterization, virulence characteristics and antimicrobial resistance of Cronobacter species from ready-to-eat foods 


\begin{tabular}{|c|c|c|c|c|c|c|c|c|c|c|c|c|c|}
\hline \multirow[b]{3}{*}{ No } & \multirow[b]{3}{*}{$\begin{array}{l}\text { Isolate } \\
\text { No }\end{array}$} & \multirow[b]{3}{*}{ Origin } & \multirow{3}{*}{$\begin{array}{l}\text { Biochemical } \\
\text { identification } \\
\text { a }\end{array}$} & \multicolumn{4}{|c|}{ Molecular characterization } & \multicolumn{4}{|c|}{ Virulence characterization } & \multicolumn{2}{|c|}{ Antimicrobial Resistance } \\
\hline & & & & \multicolumn{2}{|c|}{$\begin{array}{l}\text { Genus- } \\
\text { specific }\end{array}$} & \multicolumn{2}{|c|}{ Species-specific } & \multicolumn{2}{|c|}{ Genotypic } & \multicolumn{2}{|c|}{ Phenotypic } & \multirow{2}{*}{ Resistance } & \multirow[b]{2}{*}{ Intermediate } \\
\hline & & & & $\begin{array}{l}16 \mathrm{~S} \\
\text { rRNA }\end{array}$ & $\operatorname{glu} A$ & PCR $r p o B$ & $\begin{array}{l}\text { M-PCR } \\
C g c A\end{array}$ & $o m p A$ & $\overline{z p x}$ & $\begin{array}{l}\text { Biofilm } \\
\text { formation }\end{array}$ & $\mathrm{SP}^{\mathrm{b}}$ & & \\
\hline 1 & TT-1 & Dessert & $\begin{array}{l}C . \\
\text { malonaticus }\end{array}$ & + & + & C. sakazakii & C. sakazakii & + & + & Moderate & + & $\mathrm{KF}$ & - \\
\hline 2 & TT-2 & Dessert & C. sakazakii & + & + & C. sakazakii & C. sakazakii & + & + & Moderate & + & - & $\begin{array}{l}\text { FOX, KF, } \\
\text { PRL }\end{array}$ \\
\hline 3 & TT-3 & Dessert & $\begin{array}{l}\text { C. } \\
\text { dublinensis }\end{array}$ & + & + & $\begin{array}{l}C . \\
\text { malonaticus }\end{array}$ & $\mathrm{NI}^{\mathrm{c}}$ & + & - & Weak & + & $\mathrm{KF}$ & AMP \\
\hline 4 & TT-4 & Dessert & $\begin{array}{l}\text { C. } \\
\text { malonaticus }\end{array}$ & + & + & $\begin{array}{l}C . \\
\text { malonaticus }\end{array}$ & $\begin{array}{l}C . \\
\text { malonaticus }\end{array}$ & + & + & Absent & + & FOX, KF & PRL, TZP \\
\hline 5 & TT-5 & Dessert & $\begin{array}{l}\text { C. } \\
\text { malonaticus }\end{array}$ & + & + & C. sakazakii & C. sakazakii & + & + & Moderate & + & - & FOX, KF \\
\hline 6 & TT-6 & Dessert & $\begin{array}{l}\text { C. } \\
\text { malonaticus }\end{array}$ & + & + & $\begin{array}{l}C . \\
\text { malonaticus }\end{array}$ & $\begin{array}{l}C . \\
\text { malonaticus }\end{array}$ & + & + & Weak & + & FOX, KF & - \\
\hline 7 & TT-7 & Dessert & $\begin{array}{l}\text { C. } \\
\text { muytjensii }\end{array}$ & + & + & $\begin{array}{l}\text { C. } \\
\text { muytjensii }\end{array}$ & NI & + & + & Moderate & + & $\mathrm{AMP}, \mathrm{KF}$ & PRL \\
\hline 8 & TT-8 & Dessert & C. sakazakii & + & + & C. sakazakii & C. sakazakii & + & + & Weak & + & $\mathrm{KF}$ & FOX \\
\hline 9 & TT-9 & Dessert & $\begin{array}{l}\text { C. } \\
\text { dublinensis }\end{array}$ & + & - & $\begin{array}{l}C . \\
\text { dublinensis }\end{array}$ & $\mathrm{NI}$ & + & + & Weak & + & $\begin{array}{l}\text { AMC, } \\
\text { FOX, KF }\end{array}$ & IPM \\
\hline 10 & TT-10 & Dessert & $\begin{array}{l}\text { C. } \\
\text { malonaticus }\end{array}$ & + & + & C. sakazakii & C. sakazakii & + & + & Moderate & + & CTX, KF & - \\
\hline 11 & TT-11 & Dessert & $\begin{array}{l}\text { C. } \\
\text { dublinensis }\end{array}$ & + & + & $\begin{array}{l}\text { C. } \\
\text { dublinensis }\end{array}$ & NI & + & + & Weak & + & $\mathrm{KF}$ & CTX, PRL \\
\hline 12 & TT-12 & Dessert & C. sakazakii & + & + & C. sakazakii & C. sakazakii & + & + & Weak & + & $\begin{array}{l}\text { CTX, FOX, } \\
\text { KF }\end{array}$ & AMC, NA \\
\hline 13 & TT-13 & Dessert & C. sakazakii & + & + & C. sakazakii & C. sakazakii & + & + & Weak & + & $\begin{array}{l}\text { CTX, FOX, } \\
\text { KF }\end{array}$ & FEP, PRL \\
\hline 14 & TT-14 & Dessert & C. sakazakii & + & + & C. sakazakii & C. sakazakii & + & + & Moderate & + & $\mathrm{KF}$ & $\begin{array}{l}\text { AMP, FEP, } \\
\text { FOX }\end{array}$ \\
\hline 15 & CK-1 & $\begin{array}{l}\text { Cig } \\
\text { kofte }\end{array}$ & $\begin{array}{l}C . \\
\text { malonaticus }\end{array}$ & + & + & $\begin{array}{l}\text { C. } \\
\text { malonaticus }\end{array}$ & $\begin{array}{l}\text { C. } \\
\text { malonaticus }\end{array}$ & + & + & Weak & + & $\begin{array}{l}\text { ATM, KF, } \\
\text { NA }\end{array}$ & $\begin{array}{l}\text { CIP, FOX, } \\
\text { PRL }\end{array}$ \\
\hline 16 & $\mathrm{CK}-2$ & $\begin{array}{l}\text { Cig } \\
\text { kofte }\end{array}$ & C. sakazakii & + & + & C. sakazakii & C. sakazakii & + & + & Moderate & + & $\mathrm{KF}$ & $\begin{array}{l}\text { AMC, AMP, } \\
\text { FEP }\end{array}$ \\
\hline 17 & CK-3 & $\begin{array}{l}\text { Cig } \\
\text { kofte }\end{array}$ & $\begin{array}{l}C . \\
\text { malonaticus }\end{array}$ & + & + & $\begin{array}{l}C . \\
\text { malonaticus }\end{array}$ & $\begin{array}{l}C . \\
\text { malonaticus }\end{array}$ & + & + & Weak & + & $\mathrm{KF}$ & $\begin{array}{l}\text { AMC, CTX, } \\
\text { FOX }\end{array}$ \\
\hline 18 & $\mathrm{CK}-4$ & $\begin{array}{l}\text { Cig } \\
\text { kofte }\end{array}$ & C. sakazakii & + & + & C. sakazakii & C. sakazakii & + & + & Weak & + & $\begin{array}{l}\text { AMP, FEP, } \\
\text { FOX, KF, } \\
\text { NA }\end{array}$ & $\mathrm{TE}$ \\
\hline 19 & CK-5 & $\begin{array}{l}\text { Cig } \\
\text { kofte }\end{array}$ & C. turicensis & + & + & C. sakazakii & C. sakazakii & + & + & Moderate & + & AMP & $\mathrm{KF}$ \\
\hline 20 & CK-6 & $\begin{array}{l}\text { Cig } \\
\text { kofte }\end{array}$ & C. sakazakii & + & + & C. sakazakii & C. sakazakii & + & + & Weak & + & $\mathrm{AMP}, \mathrm{KF}$ & FOX \\
\hline 21 & CK-7 & $\begin{array}{l}\text { Cig } \\
\text { kofte }\end{array}$ & C. sakazakii & + & + & C. sakazakii & C. sakazakii & + & + & Absent & + & $\begin{array}{l}\text { ATM, KF, } \\
\text { NA }\end{array}$ & CTX, FEP \\
\hline 22 & CK-8 & $\begin{array}{l}\text { Cig } \\
\text { kofte }\end{array}$ & $\begin{array}{l}C . \\
\text { malonaticus }\end{array}$ & + & + & C. sakazakii & C. sakazakii & + & + & Moderate & + & $\mathrm{KF}$ & - \\
\hline 23 & CK-9 & $\begin{array}{l}\text { Cig } \\
\text { kofte }\end{array}$ & $\begin{array}{l}\text { C. } \\
\text { malonaticus }\end{array}$ & + & - & $\begin{array}{l}\text { C. } \\
\text { malonaticus }\end{array}$ & NI & + & + & Moderate & + & $\begin{array}{l}\text { AMC, } \\
\text { AMP, FOX, } \\
\text { KF }\end{array}$ & - \\
\hline 24 & CK-10 & $\begin{array}{l}\text { Cig } \\
\text { kofte }\end{array}$ & C. sakazakii & + & + & C. sakazakii & C. sakazakii & + & + & Moderate & + & FEP, KF & IPM \\
\hline 25 & CK-11 & $\begin{array}{l}\text { Cig } \\
\text { kofte }\end{array}$ & C. sakazakii & + & + & C. sakazakii & C. sakazakii & + & + & Weak & + & $\mathrm{KF}$ & - \\
\hline 26 & CK-12 & $\begin{array}{l}\text { Cig } \\
\text { kofte }\end{array}$ & C. sakazakii & + & + & C. sakazakii & C. sakazakii & + & + & Weak & + & FOX, KF & FEP \\
\hline 27 & CK-13 & $\begin{array}{l}\text { Cig } \\
\text { kofte }\end{array}$ & C. sakazakii & + & + & C. sakazakii & C. sakazakii & + & + & Weak & + & FOX, KF & - \\
\hline 28 & CK-14 & $\begin{array}{l}\text { Cig } \\
\text { kofte }\end{array}$ & $\begin{array}{l}C . \\
\text { malonaticus }\end{array}$ & + & + & $\begin{array}{l}C . \\
\text { malonaticus }\end{array}$ & $\begin{array}{l}C . \\
\text { malonaticus }\end{array}$ & + & + & Moderate & + & - & $\mathrm{KF}$ \\
\hline 29 & CK-15 & $\begin{array}{l}\text { Cig } \\
\text { kofte }\end{array}$ & C. sakazakii & + & + & C. sakazakii & C. sakazakii & + & + & Weak & + & FEP, KF & FOX, NA \\
\hline 30 & P-1 & Cheese & C. sakazakii & + & + & C. sakazakii & C. sakazakii & + & + & Weak & + & FOX, KF & CTX \\
\hline 31 & $\mathrm{P}-2$ & Cheese & C. sakazakii & + & + & $\begin{array}{l}C . \\
\text { malonaticus }\end{array}$ & $\begin{array}{l}C . \\
\text { malonaticus }\end{array}$ & + & + & Absent & + & FOX, KF & $\begin{array}{l}\text { AMP, CTX, } \\
\text { FEP }\end{array}$ \\
\hline 32 & $\mathrm{P}-3$ & Cheese & C. sakazakii & + & + & C. sakazakii & C. sakazakii & + & + & Weak & + & $\mathrm{KF}$ & $\begin{array}{l}\text { CTX, FEP, } \\
\text { FOX }\end{array}$ \\
\hline 33 & KV-1 & Kavurma & C. sakazakii & + & + & C. sakazakii & C. sakazakii & + & + & Weak & + & FOX, KF & $\begin{array}{l}\text { AMP, NA, } \\
\text { TZP }\end{array}$ \\
\hline 34 & $\mathrm{KV}-2$ & Kavurma & C. sakazakii & + & + & C. sakazakii & C. sakazakii & + & + & Weak & + & FOX, KF & CIP \\
\hline
\end{tabular}




\begin{tabular}{|c|c|c|c|c|c|c|c|c|c|c|c|c|c|}
\hline 35 & KV-3 & Kavurma & $\begin{array}{l}\text { C. } \\
\text { malonaticus }\end{array}$ & + & + & C. sakazakii & C. sakazakii & + & + & Absent & + & FOX, KF & CTX, NA \\
\hline 36 & PS-1 & Pastrami & $\begin{array}{l}\text { C. } \\
\text { malonaticus }\end{array}$ & + & - & $\begin{array}{l}\text { C. } \\
\text { malonaticus }\end{array}$ & $\begin{array}{l}\text { C. } \\
\text { malonaticus }\end{array}$ & + & + & Weak & + & $\begin{array}{l}\text { AMC, } \\
\text { AMP, FOX, } \\
\text { KF }\end{array}$ & CTX \\
\hline 37 & PS-2 & Pastrami & C. sakazakii & + & + & C. sakazakii & C. sakazakii & + & + & Moderate & + & CTX & $\begin{array}{l}\text { FEP, FOX, } \\
\text { KF, NA }\end{array}$ \\
\hline 38 & PS-3 & Pastrami & C. sakazakii & + & + & $\begin{array}{l}\text { C. } \\
\text { malonaticus }\end{array}$ & $\begin{array}{l}\text { C. } \\
\text { malonaticus }\end{array}$ & + & + & Strong & + & $\begin{array}{l}\text { ATM, KF, } \\
\text { PRL }\end{array}$ & $\mathrm{AMP}, \mathrm{MEM}$ \\
\hline 39 & PS-4 & Pastrami & C. turicensis & + & + & $\begin{array}{l}\text { C. } \\
\text { turicensis }\end{array}$ & $\begin{array}{l}\text { C. } \\
\text { turicensis }\end{array}$ & + & + & Weak & + & - & $\begin{array}{l}\text { FOX, KF, } \\
\text { TZP }\end{array}$ \\
\hline 40 & DN-1 & Doner & C. sakazakii & + & + & C. sakazakii & C. sakazakii & + & + & Moderate & + & $\mathrm{AMP}, \mathrm{KF}$ & FOX, PRL \\
\hline 41 & DN-2 & Doner & C. sakazakii & + & + & C. sakazakii & C. sakazakii & + & + & Weak & + & $\mathrm{KF}$ & $\begin{array}{l}\text { FEP, FOX, } \\
\text { NA,PRL }\end{array}$ \\
\hline 42 & DN-3 & Doner & C. sakazakii & + & + & C. sakazakii & C. sakazakii & + & + & Absent & + & $\mathrm{KF}$ & - \\
\hline 43 & DN-4 & Doner & C. sakazakii & + & + & C. sakazakii & C. sakazakii & + & + & Weak & + & CTX, KF & FOX \\
\hline 44 & DN-5 & Doner & C. sakazakii & + & + & C. sakazakii & C. sakazakii & + & + & Absent & + & $\mathrm{KF}$ & CTX, FOX \\
\hline 45 & DN-6 & Doner & $\begin{array}{l}C . \\
\text { malonaticus }\end{array}$ & + & + & $\begin{array}{l}C . \\
\text { malonaticus }\end{array}$ & $\begin{array}{l}\text { C. } \\
\text { malonaticus }\end{array}$ & + & + & Weak & + & FOX & $\mathrm{KF}, \mathrm{PRL}$ \\
\hline 46 & DN-7 & Doner & $\begin{array}{l}\text { C. } \\
\text { malonaticus }\end{array}$ & + & + & C. sakazakii & C. sakazakii & + & + & Weak & + & $\begin{array}{l}\text { CTX, FOX, } \\
\text { KF }\end{array}$ & - \\
\hline 47 & B-1 & Spice & C. sakazakii & + & + & $\begin{array}{l}C . \\
\text { malonaticus }\end{array}$ & $\begin{array}{l}C . \\
\text { malonaticus }\end{array}$ & + & + & Weak & + & $\mathrm{KF}$ & AMP \\
\hline 48 & B-2 & Spice & $\begin{array}{l}C . \\
\text { malonaticus }\end{array}$ & + & + & C. sakazakii & C. sakazakii & + & + & Moderate & + & $\mathrm{KF}$ & $\begin{array}{l}\text { AK, AMC, } \\
\text { AMP, CIP, } \\
\text { CTX,MEM, } \\
\text { PRL }\end{array}$ \\
\hline 49 & B-3 & Spice & $\begin{array}{l}\text { C. } \\
\text { dublinensis }\end{array}$ & + & + & $\begin{array}{l}\text { C. } \\
\text { dublinensis }\end{array}$ & $\begin{array}{l}\text { C. } \\
\text { dublinensis }\end{array}$ & + & + & Absent & + & AMP & - \\
\hline 50 & B-4 & Spice & $\begin{array}{l}C . \\
\text { malonaticus }\end{array}$ & + & + & $\begin{array}{l}C . \\
\text { malonaticus }\end{array}$ & $\begin{array}{l}C . \\
\text { malonaticus }\end{array}$ & + & + & Weak & + & $\begin{array}{l}\text { CTX, FOX, } \\
\text { KF }\end{array}$ & $\begin{array}{l}\text { AMC, AMP, } \\
\text { FEP, TZP }\end{array}$ \\
\hline 51 & B-5 & Spice & C. sakazakii & + & + & C. sakazakii & C. sakazakii & + & + & Weak & + & $\mathrm{KF}$ & $\begin{array}{l}\text { AK, AMP, } \\
\text { CTX, FOX, } \\
\text { PRL }\end{array}$ \\
\hline 52 & B-6 & Spice & C. sakazakii & + & + & C. sakazakii & C. sakazakii & + & + & Strong & + & $\mathrm{AMP}, \mathrm{KF}$ & FOX \\
\hline 53 & B-7 & Spice & C. sakazakii & + & + & C. sakazakii & C. sakazakii & + & + & Moderate & + & $\mathrm{KF}$ & FOX \\
\hline 54 & B-8 & Spice & $\begin{array}{l}\text { C. } \\
\text { muytjensii }\end{array}$ & + & + & $\begin{array}{l}\text { C. } \\
\text { dublinensis }\end{array}$ & $\begin{array}{l}\text { C. } \\
\text { dublinensis }\end{array}$ & + & + & Weak & + & $\mathrm{KF}$ & - \\
\hline 55 & C-1 & Cereal & C. turicensis & + & + & $\begin{array}{l}\text { C. } \\
\text { turicensis }\end{array}$ & NI & + & + & Weak & + & AMP, ATM & NA, TE \\
\hline 56 & $\mathrm{C}-2$ & Cereal & C. sakazakii & + & + & C. sakazakii & C. sakazakii & + & + & Moderate & + & $\mathrm{KF}$ & FOX \\
\hline 57 & $\mathrm{C}-3$ & Cereal & $\begin{array}{l}\text { C. } \\
\text { malonaticus }\end{array}$ & + & + & $\begin{array}{l}C . \\
\text { malonaticus }\end{array}$ & $\begin{array}{l}\text { C. } \\
\text { malonaticus }\end{array}$ & + & + & Weak & + & $\begin{array}{l}\text { CTX, FOX, } \\
\text { KF }\end{array}$ & FEP, IPM \\
\hline 58 & $\mathrm{C}-4$ & Cereal & $\begin{array}{l}\text { C. } \\
\text { universalis }\end{array}$ & + & + & C. sakazakii & C. sakazakii & + & + & Absent & + & AMP & - \\
\hline 59 & D-1 & $\begin{array}{l}\text { Ice } \\
\text { cream }\end{array}$ & $\begin{array}{l}\text { C. } \\
\text { malonaticus }\end{array}$ & + & + & C. sakazakii & C. sakazakii & + & + & Weak & + & FOX, KF & AMP, FEP \\
\hline 60 & D-2 & $\begin{array}{l}\text { Ice } \\
\text { cream }\end{array}$ & C. sakazakii & + & + & C. sakazakii & C. sakazakii & + & + & Moderate & + & $\mathrm{KF}$ & $\begin{array}{l}\text { AK, CTX, } \\
\text { FEP, FOX, } \\
\text { IPM }\end{array}$ \\
\hline 61 & D-3 & $\begin{array}{l}\text { Ice } \\
\text { cream }\end{array}$ & C. sakazakii & + & + & C. sakazakii & C. sakazakii & + & + & Moderate & + & FOX, KF & NA \\
\hline 62 & D-4 & $\begin{array}{l}\text { Ice } \\
\text { cream }\end{array}$ & C. sakazakii & + & + & $\begin{array}{l}C . \\
\text { malonaticus }\end{array}$ & NI & + & + & Moderate & + & AMP & C, FEP \\
\hline 63 & D-5 & $\begin{array}{l}\text { Ice } \\
\text { cream }\end{array}$ & $\begin{array}{l}\text { C. } \\
\text { muytjensii }\end{array}$ & + & - & $\begin{array}{l}\text { C. } \\
\text { muytjensii }\end{array}$ & NI & + & + & Weak & + & AMP & $\mathrm{C}$ \\
\hline 64 & SL-1 & Salad & C. sakazakii & + & + & C. sakazakii & C. sakazakii & + & + & Weak & + & $\mathrm{KF}$ & CTX, FOX \\
\hline
\end{tabular}

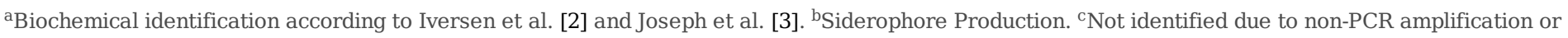
non-specific PCR amplification.

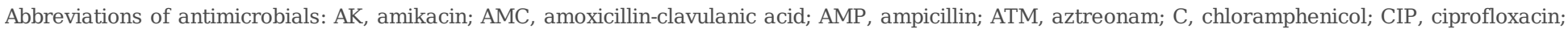

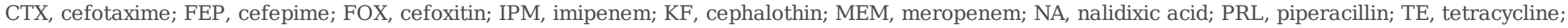
$\mathrm{TZP}$, piperacillin/tazobactam.

Table 3 Primer sequences used in PCR assays 


\begin{tabular}{|c|c|c|c|c|}
\hline Target Gene & Primer & Primer Sequence $\left(5^{\prime} \rightarrow 3^{\prime}\right)$ & Product Size (bp) & Reference \\
\hline 16S rRNA & $\begin{array}{l}\text { Saka-1 } \\
\text { Saka-2b }\end{array}$ & $\begin{array}{l}\text { ACA GGG AGC AGC TTG CTG C } \\
\text { TCC CGC ATC TCT GCA GGA }\end{array}$ & 952 & {$[25]$} \\
\hline gluA & $\begin{array}{l}\text { EsAgf } \\
\text { EsAgr }\end{array}$ & $\begin{array}{l}\text { TGA AAG CAA TCG ACA AGA AG } \\
\text { ACT CAT TAC CCC TCC TGA TG }\end{array}$ & 1680 & {$[24]$} \\
\hline \multirow[t]{6}{*}{ rров } & $\begin{array}{l}\text { Csakf } \\
\text { Csakr } \\
\text { Cmalf } \\
\text { Cmalr }\end{array}$ & $\begin{array}{l}\text { ACG CCA AGC CTA TCT CCG CG } \\
\text { ACG GTT GGC GTC ATC GTG } \\
\text { CGT CGT ATC TCT GCT CTC } \\
\text { AGG TTG GTG TTC GCC TGA }\end{array}$ & $\begin{array}{l}514 \\
251\end{array}$ & {$[26]$} \\
\hline & $\begin{array}{l}\text { Cmuyf } \\
\text { Cmuyr }\end{array}$ & $\begin{array}{l}\text { TGT CCG TGT ATG CGC AGA CC } \\
\text { TGT TCG CAC CCA TCA ATG CG }\end{array}$ & 289 & \\
\hline & $\begin{array}{l}\text { Cdublf } \\
\text { Cdublr }\end{array}$ & $\begin{array}{l}\text { GCA CAA GCG TCG TAT CTC C } \\
\text { TTG GCG TCA TCG TGT TCC }\end{array}$ & 418 & \\
\hline & $\begin{array}{l}\text { Cturf } \\
\text { Cturr }\end{array}$ & $\begin{array}{l}\text { CGG TAA AAG AGT TCT TCG GC } \\
\text { GTA CCG CCA CGT TTC GCC }\end{array}$ & 628 & \\
\hline & $\begin{array}{l}\text { Cgenomf } \\
\text { Cgenomr }\end{array}$ & $\begin{array}{l}\text { ACA AAC GTC GTA TCT CTG CG } \\
\text { AGC ACG TTC CAT ACC GGT C }\end{array}$ & 506 & \\
\hline & $\begin{array}{l}\text { Ccon-f } \\
\text { Ccon-r }\end{array}$ & $\begin{array}{l}\text { AAC GCC AAG CCA ATC TCG } \\
\text { GTA CCG CCA CGT TTT GCT }\end{array}$ & 689 & {$[27]$} \\
\hline \multirow[t]{8}{*}{$\operatorname{CgCA}$} & $\mathrm{Cdm}-469 \mathrm{R}^{\mathrm{a}}$ & CCA CAT GGC CGA TAT GCA CGC C & & {$[28]$} \\
\hline & Cdub-40F & GAT ACC TCT CTG GGC CGC AGC & 430 & \\
\hline & Cmuy-209F & TTC TTC AGG CGG AGC TGA CCT & 260 & \\
\hline & Cmstu-825F ${ }^{b}$ & GGT GGC SGG GTA TGA CAA AGA C & & \\
\hline & Ctur-1036R & TCG CCA TCG AGT GCA GCG TAT & 211 & \\
\hline & Cuni-1133R & GAA ACA GGC TGT CCG GTC ACG & 308 & \\
\hline & Csak-1317R & GGC GGA CGA AGC CTC AGA GAG T & 492 & \\
\hline & Cmal-1410R & GGT GAC CAC ACC TTC AGG CAG A & 585 & \\
\hline ompA & $\begin{array}{l}\text { ESSF } \\
\text { ESSR } \\
\end{array}$ & $\begin{array}{l}\text { GGA TTT AAC CGT GAA CTT TTC C } \\
\text { CGC CAG CGA TGT TAG AAG A }\end{array}$ & 469 & {$[14]$} \\
\hline$z p x$ & $\begin{array}{l}\text { Es-ProF } \\
\text { Es-ProR }\end{array}$ & $\begin{array}{l}\text { GAA AGC GTA TAA GCG CGA TTC } \\
\text { GTT CCA GAA GGC GTT CTG GT }\end{array}$ & 94 & [13] \\
\hline ERIC & $\begin{array}{l}\text { ERIC1R } \\
\text { ERIC2 } \\
\end{array}$ & $\begin{array}{l}\text { ATG TAA GCT CCT GGG GAT TCA C } \\
\text { AAG TAA GTG ACT GGG GTG AGC G }\end{array}$ & & {$[23]$} \\
\hline
\end{tabular}

aThe PCR primer Cdm-469R was used in multiplex reactions, with primers Cdub-40F and Cmuy-209F identifying C. dublinensis and C. muytjensii strains, respectively. ${ }^{b}$ The PCR primer Cmstu-825F was used in multiplex reactions, with primers Ctur-1036R, Cuni-1133R, Csak1317R and Cmal-1410R identifying C. turicensis, C. universalis, C. sakazakii and C. malonaticus strains, respectively.

\section{Figures}




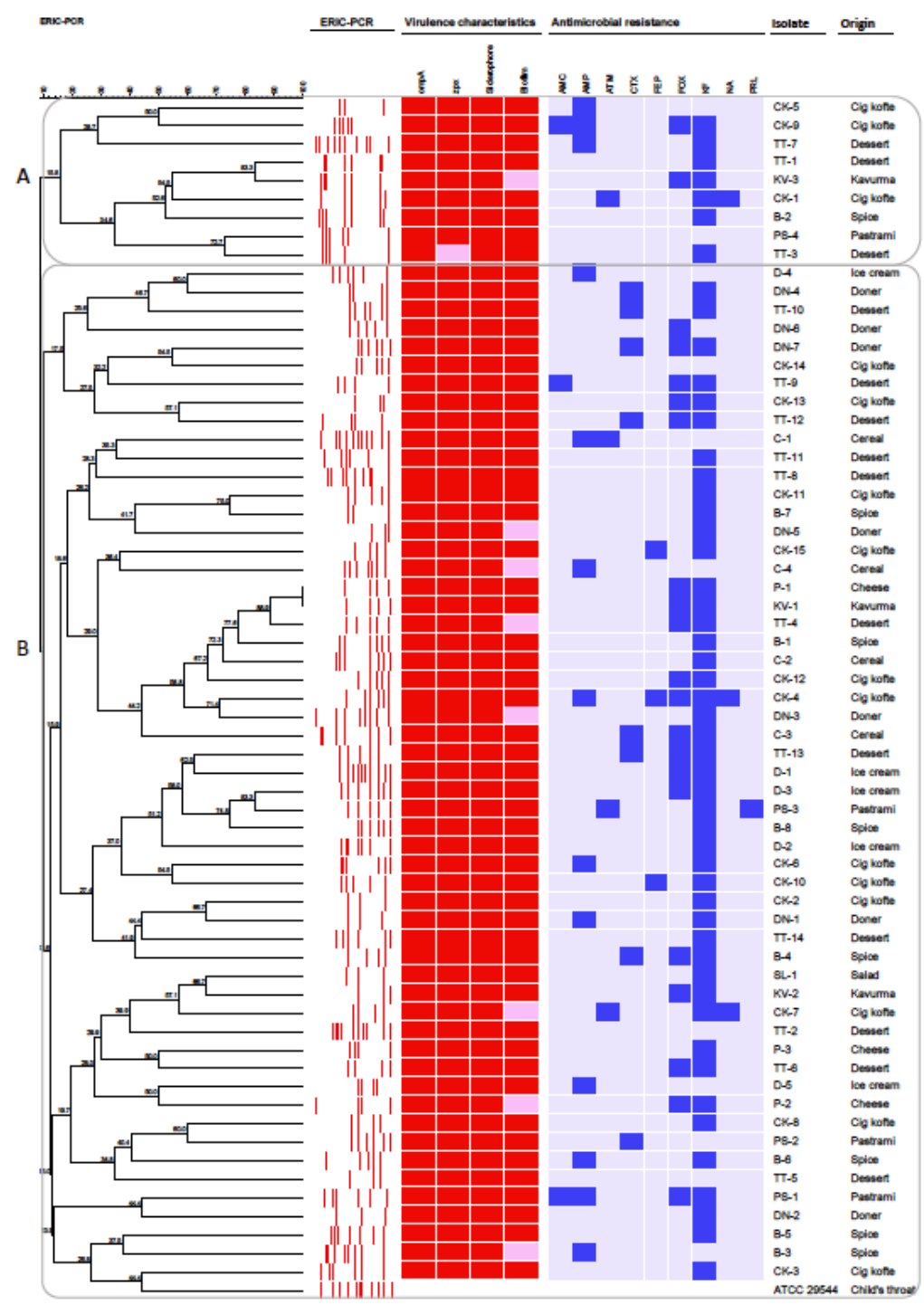

\section{Figure 1}

ERIC-PCR patterns, virulence characteristics and antimicrobial resistance profiles of Cronobacter isolates in this study. Dendrogram was constructed using BioNumerics version 7.6. The red box indicates the presence of the gene while the pink box indicates the absence of the gene. The dark blue box indicates resistance to a particular antimicrobial whereas the light blue box indicates negative result of resistance to a particular antimicrobial. Abbreviations of antimicrobials: AMC, amoxicillin-clavulanic acid; AMP, ampicillin; ATM, aztreonam; CTX, cefotaxime; FEP, cefepime; FOX, cefoxitin; KF, cephalothin; NA, nalidixic acid; PRL, piperacillin. 


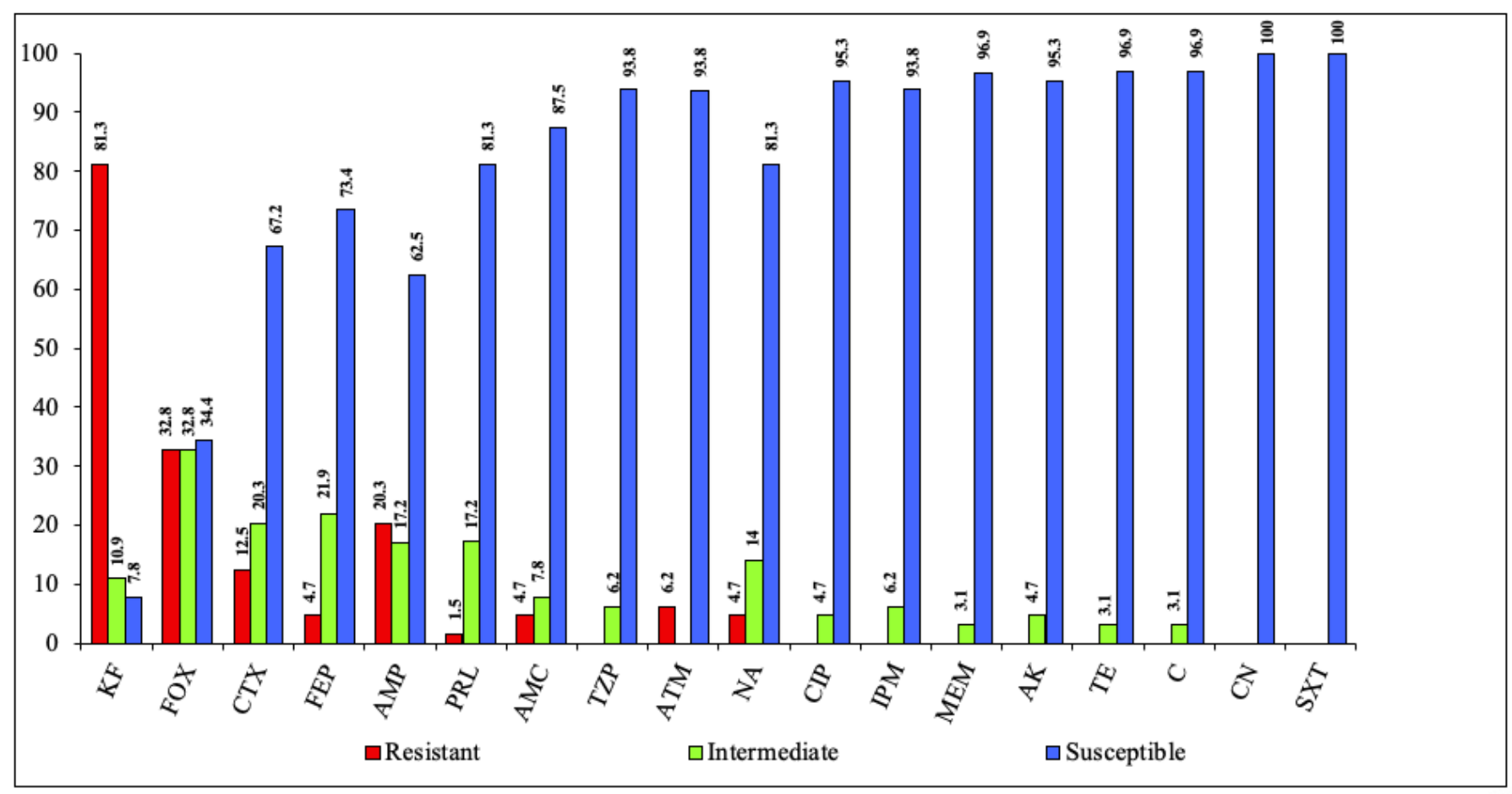

Figure 2

Antimicrobial susceptibility of the 64 Cronobacter isolates from ready-to-eat foods. Abbreviations of antimicrobials: AK, amikacin; AMC, amoxicillin-clavulanic acid; AMP, ampicillin; ATM, aztreonam; C, chloramphenicol; CIP, ciprofloxacin; CN, gentamicin; CTX, cefotaxime; FEP, cefepime; FOX, cefoxitin; IPM, imipenem; KF, cephalothin; MEM, meropenem; NA, nalidixic acid; PRL, piperacillin; SXT, trimethoprim/sulfamethoxazole; TE, tetracycline; TZP, piperacillin/tazobactam. 